\title{
Перспективні можливості запобігання появі та прогресуванню фіброзу печінки
}

\author{
О.В. Швець \\ Українська гастроентерологічна асоціація
}

Анотація. У статті розглянуто патофізіологічні механізми фіброзу печінки. Зазначено, що фіброз печінки - ознака прогресування хронічних дифузних захворювань печінки, його уповільнення та регрес $\epsilon$ метою гепатопротекторних терапевтичних інтервенцій. Ефективна етіотропна терапія, індивідуальна дієтотерапія та застосування оптимальних гепатопротекторів спроможні запобігти появі та прогресуванню фіброзу печінки. Наведено основні засади гепатопротекторної терапії та характеристики гепатопротекторних препаратів. Представлено інноваційний комплекс похідних амінокислот із гепатопротекторними властивостями Ліводінол ${ }^{\circledR}$, який дозволяє досягнути терапевтичної мети при різних хронічних дифузних захворюваннях печінки.

Ключові слова: хронічні дифузні захворювання печінки, фіброз печінки, цироз печінки, гепатопротектори, Ліводінол ${ }^{\oplus}$.

\section{Патофізіологічні механізми фіброзу печінки}

Фіброз печінки являє собою процес загоєння ушкоджень, при якому відбуваються інкапсуляція екстрацелюлярним матриксом або формування рубця. Він з'являється майже в усіх пацієнтів із хронічними ушкодженнями печінки з різним рівнем прояву, частково залежно від причини хвороби печінки та стану організму [1]. На відміну від хронічної патології, внаслідок невідомих причин при фульмінантному гепатиті не утворюються рубці, незважаючи на наявність стимуляторів фіброгенезу, допоки не виникне хронічний процес.

Ранні фібротичні зміни виникають у місцях із найбільшим ступенем ушкодження тканин, наприклад, як результат впливу алкоголю або вірусної інфекції. Процес триває від декількох місяців до декількох років. Два винятки можна навести щодо патологічних станів у дорослих: венооклюзивні захворювання та механічні біліарні ушкодження, при яких фіброз виникає значно швидше.

Фібротичні зміни можуть бути зворотними на ранніх етапах розвитку, але прогресуючий фіброз веде до цирозу печінки. Точка, в якій він стане незворотним, достеменно невідома. Водночас існують докази того, що навіть ранні стадії цирозу можуть бути зворотними [2].

Фіброз печінки являє собою парадигму загоєння ушкоджень, і перебігає за аналогічними сценаріями порівняно з іншими тканинами, включаючи шкіру, легені, нирки, тому що залучає багато подібних клітин та медіаторів [3].

Початок розвитку фіброзу у відповідь на пошкодження печінки супроводжується змінами навколосинусоїдного простору Діссе та синусоїду, включаючи зміни на клітинному рівні та перебудову екстрацелюлярного матриксу (рис. 1). Активація зірчастих клітин зумовлює депонування рубецьформуючого матриксу. Водночас відмічаються втрата гепатоцитами мікроворсин та зникнення синусоїдних ендотеліальних фенестр із погіршенням функціонального стану печінки. Активація купферівських клітин (макрофагів) призводить до додаткової стимуляції зірчастих клітин.

Рисунок 1 Розвиток фібротичних змін на клітинному та субендотеліальному рівні

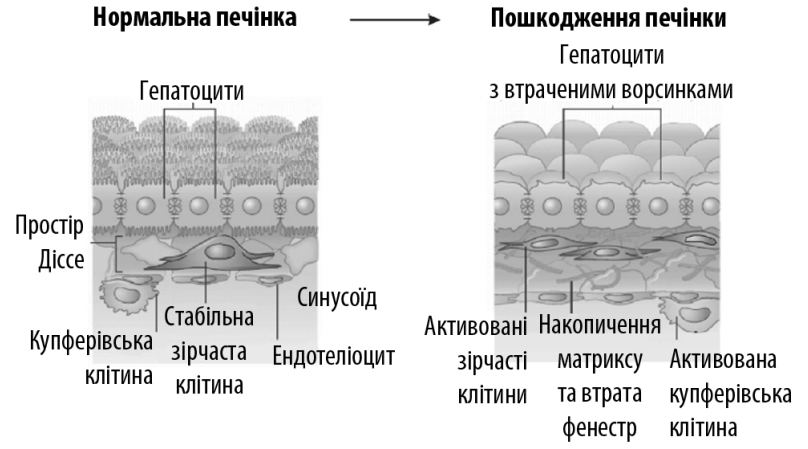

Дотепер лишаються невизначеними гістологічні маркери або специфічні зміни композиції матриксу, які свідчать про втрату можливостей відновлення морфологічної архітектури.

Водночас поява щільних циротичних ділянок із утворенням вузлів, портальною гіпертензією та ранньою печінковою недостатністю $\epsilon$ ознакою незворотних змін. Менш виражені зміни демонструють значну здатність до регресу та зворотності, особливо за можливості контролю причини пошкодження печінки (наприклад вірусний гепатит В та С, неалкогольна жирова хвороба печінки - НАЖХП). У близько 70\% пацієнтів можуть відмічати достовірний регрес цирозу після успішної противірусої терапії та баріатричної хірургії [4].

\section{Основні засади \\ гепатопротекторної терапії}

Під гепатопротекцією розуміють комплекс інтервенцій, спрямованих на запобігання прогресуванню хронічних дифузних захворювань печінки (ХДЗП) із виникненням фібротичних змін та розвитком значних порушень архітектоніки печінки. У вищезгаданий комплекс інтервенцій з метою запобігання виникненню та прогресуванню фіброзу печінки обов'язково повинні бути включені зміна способу життя, етіотропна терапія ХДЗП (у разі ії наявності і доступності) та застосування гепатопротекторних препаратів із доведеною ефективністю. Гепатопротекторні інтервенції спрямовані на досягнення специфічних цілей з урахуванням стадії ХДзП та відповідних клініко-морфологічних змін. На рис. 2 наведено профілактичні та терапевтичні цілі на прикладі НАЖХП.

Рисунок 2 Гепатопротекторні цілі при НАЖХП

\begin{tabular}{|c|c|c|c|}
\hline Група ризику & НАЖД & HACI & Цироз \\
\hline $\begin{array}{l}\text { - Профілактика } \\
\text { • } \downarrow \text { ризику }\end{array}$ & $\begin{array}{l}\text { • Зникнення } \\
\text { жирової } \\
\text { дистрофії } \\
\text { • Відсутність } \\
\text { прогресування }\end{array}$ & $\begin{array}{l}\text { - Розрішення } \\
\text { НАСГ } \\
\text { • Зупинка } \\
\text { прогресування } \\
\text { фіброзу }\end{array}$ & $\begin{array}{l}\text { - Регресія } \\
\text { захворювання } \\
\text { - Запобігання } \\
\text { декомпенсації } \\
\text { - } \downarrow \text { смертності }\end{array}$ \\
\hline \multicolumn{4}{|c|}{ Ефективність інтервенцій } \\
\hline
\end{tabular}

НАЖД— - неалкогольна жирова дистрофія печінки, НАСГ — неалкогольний стеатогепатит

Корекція способу життя передбачає підвищення фізичної активності до принаймні 30 хв на день протягом 5 днів на тиждень, виключення або принаймні значне скорочення вживання алкоголю, зменшення надмірної маси тіла, дотримання збалансованого харчування [5-7]. Низка гепатологічних професійних асоціацій, включаючи Європейську асоціацію з вивчення захворювань печінки (European Association for the Study of the Liver - 
EASL), рекомендує середземноморську дієту в якості гепатопротекторної моделі харчування, зважаючи на доведені ефекти, наведені на рис. 3 [8].

Рисунок 3 Гепатопротекторні ефекти середземноморської дієти та важливі нутрієнти цієї моделі харчування

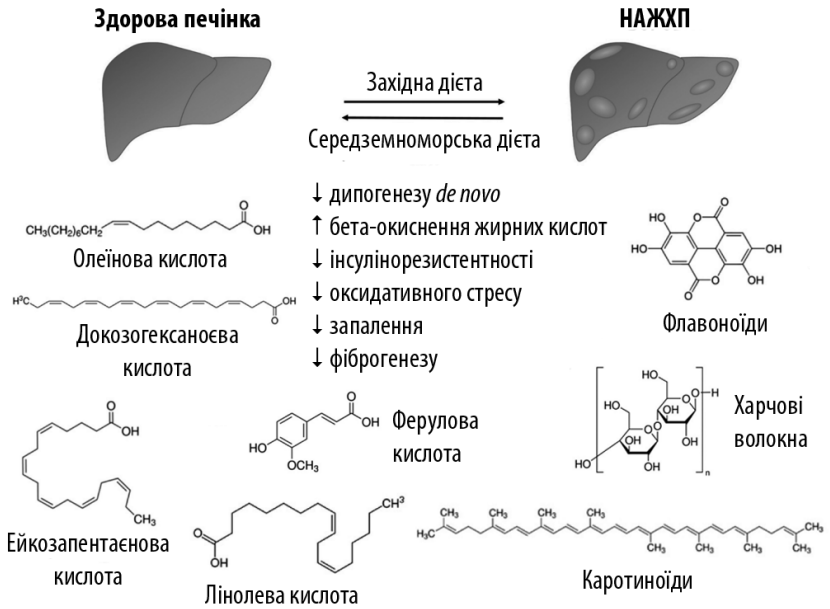

Рекомендації зі змін у харчуванні з наближенням набору продуктів та напоїв до середземноморської або іншої збалансованої моделі харчування, поліпшення харчової поведінки повинні бути індивідуальними, зрозумілими та легко відтворюваними у щоденному житті. Шаблонні рекомендації на кшталт дієти № 5 за Певзнером не повинні застосовуватися з огляду на відсутність доказів ефективності та надзвичайно низький комплаєнс.

Окремим ефективним напрямком гепатопротекції $\epsilon$ імунопрофілактика. Пацієнти із ХДЗП за наявності показань можуть бути кандидатами на щеплення від вірусного гепатиту A та B, вірусів грипу та пневмококу [9].

\section{Характеристики \\ гепатопротекторних препаратів}

Цікаво, що термін «гепатопротектори», широко застосований в українській спеціалізованій літературі, лише нещодавно з'явився у публікаціях в західних наукових джерелах. Розроблення та випробування нових препаратів, створення комбінацій досить добре відомих діючих речовин підвищують ефективність гепатопротекторної терапії. Якщо спробувати сформулювати ідеальні характеристики відповідного препарату, то найбільш важливими з них є наступні: простий спосіб доставки діючої речовини; добре переносимий/безпечний; гепатоспецифічний; вплив на надмірний розвиток сполучної тканини; зупинка прогресування фіброзу, запобігання ускладненням [10].

Найбільш значне зниження ризику виникнення та прогресування фіброзу печінки може бути досягнуте при проведенні ефективної етіотропної терапії завдяки усуненню пошкоджувального фактора та припинення його патофізіологічної дії. У таблиці перераховані можливості етіотропної терапії при ХДЗП.

Таблиця Етіотропна терапія при різних ХДЗП $[11,12]$

\begin{tabular}{ll}
\multicolumn{1}{c}{ Пошкоджувальний фактор } & \multicolumn{1}{c}{ Можливості етіотропної терапії } \\
\hline Шистосоміаз & Протигельмінтна терапія \\
\hline Біліарні ушкодження & Біліарна декомпресія \\
\hline Хвороба Вільсона, гемохроматоз & Обмеження вживання міді та заліза \\
\hline НАжХП & Баріатрична хірургія \\
\hline Медикаментозні та алкогольні ураження & $\begin{array}{l}\text { Відміна відповідних ліків, алкогольна } \\
\text { абстиненція }\end{array}$ \\
\hline
\end{tabular}

Наступним рівнем патогенетичної терапії ХДЗП є застосування препаратів, які мають протизапальну дію. Їх ефективність пов'язана зі зниженням активності гепатиту, який є проміжним етапом на шляху розвитку морфологічної перебудови у печінці, починаючи з фіброзу. Перспективні напрямки протизапальної терапії перелічені на рис. 4.

Рисунок 4 Протизапальна гепатопротекторна терапія [13]

$\begin{array}{cc}\text { Кортикостероїди } & \text { Кофеїн } \\ \text { Застосовують при алкогольному } & \text { Антифібротична дія, ймовірно, } \\ \text { та аутоімунному гепатиті } & \text { зумовлена блокадою аденозину } \\ \text { Колхіцин } & \\ \text { Продовжують застосовувати } \\ \text { у лікуванні цирозу, але } \\ \text { метааналіз рандомізованих клінічних } \\ \text { досліджень не підтверджує його } \\ \text { ефективність } \\ \text { Ерсодезоксихолева кислота } \\ \text { Еективна улікуванні первинного }\end{array}$

Як і при багатьох інших патологічних станах, патогенез яких пов'язаний із хронічним запаленням та імунною активацією, при ХДЗП великий потенціал із накопиченням відповідних доказів демонструє імуномодулююча терапія. Природні кілери (або NK-клітини) є частиною вродженої імунної системи та становлять до 50\% лейкоцитарного пулу печінки. Окрім того, що природні кілери здійснюють захист проти вірусних інфекцій, вони також пригнічують прогресування фіброзу шляхом знищення активованих зірчастих клітин [14]. Цей процес супроводжується вивільненням двох антифібротичних цитокінів - a- i $\gamma$-інтерферону. Алкоголь знижує антифібротичну активність NK-клітин, що може зумовлювати прогресування фіброзу при алкогольному гепатиті [15]. Майбутні способи лікування фіброзу мають бути спрямовані на специфічну стимуляцію природних кілерів для знищення активованих зірчастих клітин. Подібні дослідження вже виконуються на лабораторних моделях.

Багато досліджень плануються і тривають для пошуку нових можливостей для зниження активації зірчастих клітин, які відповідно до вищезазначеного відіграють провідну роль у запуску каскаду фіброгенетичних змін. Дотепер підтвердження ефективності отримано щодо добре відомих активних речовин (рис. 5).

Рисунок 5 Препарати, здатні знижувати активність зірчастих клітин печінки $[16,17]$

Інтерферони
Знижують активність генів,
що відповідають за синтез колагену,
ефективність не підтверджена
у рандомізованих клінічних
дослідженнях
Канабіноїди
Антиоксиданти
Виявляють антифібротичний ефект
$\begin{gathered}\text { Контроль оксидативного стресу запобігає } \\ \text { активації зірчастих клітин: вітамін } \mathrm{E}_{2} \\ \text { кверцетин, ресвератрол мають } \\ \text { антифібротичний потенціал }\end{gathered}$
клітин $\left(\mathrm{CB}_{1}\right.$ та $\left(\mathrm{B}_{2}\right)$

$\mathrm{CB}_{1}$ та $\mathrm{CB}_{2}$ - канабіноїдні рецептори 1-го і 2-го типу

Триваюча дискусія та дослідження з пошуку оптимальних гепатопротекторних препаратів часто спрямовані на визначення можливостей застосування амінокислот, які мають добре відомі функціональні механізми захисту гепатоцитів від ушкоджувальної дії різних інфекційних агентів та гепатотоксичних речовин.

Нещодавно в Україні з'явилася інноваційна комбінація похідних амінокислот L-глутатіону, N-ацетилцистеїну та адеметіоніну - Ліводінол ${ }^{\circledR}$. Це дієтична добавка для підтримання функції печінки, яка сприяє ії захисту та відновленню завдяки потужній детоксикаційній дії, зумовленій вмістом пероральної форми глутатіону у комплексі із компонентами, які сприяють синтезу ендогенного глутатіону.

Узагальнені патофізіологічні ефекти складових комплексу Ліводінол ${ }^{\circledast}$ проілюстровані на рис. 6: 


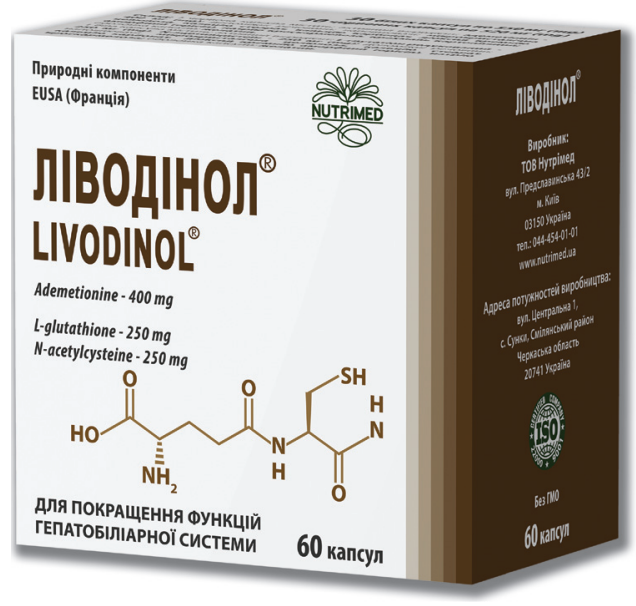

Рисунок 6 Узагальнені патофізіологічні ефекти складових комплексу Ліводінол

\begin{tabular}{|c|c|c|}
\hline L-глутатіон & N-ацетилцистеїн & Адеметіонін \\
\hline $\begin{array}{c}\text { Нейтралізація вільних } \\
\text { радикалів, продуктів } \\
\text { перекисного окиснення }\end{array}$ & $\begin{array}{c}\text { Єобов'язковим } \\
\text { компонентом для синтезу } \\
\text { антиоксиданту глутатіону }\end{array}$ & $\begin{array}{c}\text { Реалізує холеретичну дію } \\
\text { завдяки поліпшенню } \\
\text { внутрішньоклітинного } \\
\text { транспорту жовчних } \\
\text { кислот }\end{array}$ \\
\hline $\begin{array}{c}\text { Безпечний метаболізм } \\
\text { та екскреція } \\
\text { ксенобіотиків, захист } \\
\text { мембран та інших } \\
\text { компонентів гепатоцитів }\end{array}$ & $\begin{array}{c}\text { Сприяє реалізації } \\
\text { антиоксидантних } \\
\text { та дезінтоксикаційних } \\
\text { ефектів на рівні печінки } \\
\text { та всього організму }\end{array}$ & $\begin{array}{c}\text { Ефект доповнюється } \\
\text { холекінетичною дією } \\
\text { внаслідок нормалізації } \\
\text { моторики жовчовивідних } \\
\text { шляхів }\end{array}$ \\
\hline
\end{tabular}

Глутатіон - найважливіший клітинний антиоксидант, що міститься в усіх клітинах організму. Найвища його концентрація спостерігається у печінці та становить $90 \%$ усього фізіологічного рівня глутатіону, що обумовлює його важливу роль у детоксикації організму шляхом ліквідації вільних радикалів. Глутатіон не тільки індукує вироблення у печінці детоксикаційних ферментів, але й захищає клітини самої печінки від пошкоджень і сприяє їх регенерації. Тому його нестача характерна практично для усіх хронічних захворювань печінки. Вироблення глутатіону в організмі залежить від віку. Починаючи з 28 років його синтез знижується з кожним роком приблизно на 1\%; при зниженні рівня глутатіону до 90\% процес погіршення стану здоров'я стає незворотним. Саме тому підтримання фізіологічного рівня глутатіону вкрай важливе як при хронічних ураженнях печінки, так і для профілактики вікових хвороб.

$\mathrm{N}$-ацетилцистеїн — відома молекула, що використовується як антидот при отруєнні парацетамолом. Останнім часом у великій кількості клінічних досліджень повідомлялося про перспективу застосування $\mathrm{N}$-ацетилцистеїну у якості попередника глутатіону при патологіях, що пов'язані з його дефіцитом. N-ацетилцистеїн $\epsilon$ стабільною формою амінокислоти L-цистеїну та забезпечує надходження цистеїну у клітину, який $\epsilon$ одним із компонентів глутатіону. Саме концентрація L-цистеїну у клітині відіграє ключову роль у швидкості утворення відновленого глутатіону. Таким чином $\mathrm{N}$-ацетилцистеїн розглядається як потужний антиоксидант сам по собі і як стабільний попередник глутатіону у клітинах з його дефіцитом. N-ацетилцистеїн доцільно використовувати для підтримання фізіологічного рівня глутатіону. Крім цього, він має виражені антиоксидантні та детоксикаційні властивості, які підсилюють дію інших компонентів комплексу Ліводінол ${ }^{\circledR}$ при токсичних ураженнях печінки та вікових змінах в організмі.

Адеметіонін (S-аденозил-L-метіонін) - відома субстанція 3 широким та мультимодальним впливом на біохімічні процеси як в печінці, так і в організмі в цілому. У печінці S-аденозил-L-метіонін бере участь у реакціях трансметилювання, транссульфурування та амінопропілювання. Порушення транссульфурування призводить до зниження рівня глутатіону в гепатоцитах, що може призвести до їх пошкодження та некрозу у результаті оксидативного стресу.
Якщо кількість утворених вільних радикалів перевищує нейтралізуючу здатність глутатіону, відбувається значне пошкодження клітин. Більше того, виснаження глутатіону в печінці внаслідок ії ушкодження призводить до інактивації S-аденозил-метіонінсинтетази. Це, в свою чергу, порушує процес транссульфурування, і відбувається подальше зменшення кількості глутатіону. Останній $\epsilon$ частиною біохімічного захисту S-аденозил-метіонін-синтетази, тобто цей процес регулюється зворотним зв'язком.

Таким чином, усі компоненти комплексу Ліводінол ${ }^{\circledR}$ пов'язані тісним біохімічним зв'язком і сприяють підтриманню та нормалізації метаболічних процесів у печінці.

Ліводінол ${ }^{\circledast}$ дозволяє отримувати синергічні гепатопротекторні ефекти та рекомендований до вживання при: пошкодженні печінки внаслідок токсичної дії алкоголю, лікарських засобів, ксенобіотиків; НАЖХП; вірусному гепатиті; гепатозі, стеатозі, цирозі печінки; печінковій енцефалопатії.

Для відновлення рівня глутатіону та адеметіоніну у гепатоцитах, реалізації антиоксидантної дії та нейтралізації гепатотоксичних речовин, сприяння відновленню печінки Ліводінол ${ }^{\circledast}$ рекомендовано вживати курсом тривалістю 1-3 міс (щодня по 2 червоні капсули за 30 хв до сніданку та 2 білі капсули за 30 хв до вечері).

\section{Висновки}

Фіброз печінки - ознака прогресування ХДЗП, його уповільнення та регрес $\epsilon$ метою гепатопротекторних терапевтичних інтервенцій.

Ефективна етіотропна терапія, індивідуальна дієтотерапія та застосування оптимальних гепатопротекторів спроможні запобігти появі та прогресуванню фіброзу печінки.

Комбінація амінокислот з гепатопротекторними властивостями Ліводінол ${ }^{\circledR}$ дозволяє досягнути терапевтичної мети при різних ХДЗП.

\section{Список використаної літератури/References:}

1. Friedman S.L. (2010) Evolving challenges in hepatic fibrosis. Nat. Rev. Gastroenterol. Hepatol., 7:425.

2. Ismair M.G., Stieger B., Cattori V. et al. (2001) Hepatic uptake of cholecystokinin octapeptide by organic anion-transporting polypeptides OATP4 and OATP8 of rat and human liver. Gastroenterol., 121: 1185.

3. Friedman S.L. (2008) Hepatic stellate cells: protean, multifunctional, and enigmatic cells of the liver. Physiol. Rev., 88: 125.

4. Marcellin P., Gane E., Buti M. et al. (2013) Regression of cirrhosis during treatment with tenofovir disoproxil fumarate for chronic hepatitis B: a 5-year open-label follow-up study. Lancet, 381: 468.

5. WHO (2020) WHO guidelines on physical activity and sedentary behaviour. Geneva.

6. WHO (2018) Global status report on alcohol and health 2018. Geneva.

7. Zelber-Sagi S., Salomone F., Mlynarsky L. (2017) The Mediterranean dietary pattern as the diet of choice for non-alcoholic fatty liver disease: Evidence and plausible mechanisms. Liver Int., 37(7): 936-949. doi: 10.1111/liv.13435

8. European Association for the Study of the Liver (EASL), European Association for the Study of Diabetes (EASD), European Association for the Study of Obesity (EASO) (2016) EASL-EASDEASO Clinical Practice Guidelines for the management of non-alcoholic fatty liver disease. J. Hepatol., 64(6): 1388-1402. doi: 10.1016/j.jhep.2015.11.004

9. Alter M.J. (2012) Vaccinating patients with chronic liver disease. Gastroenterol. Hepatol. (N.Y.), $8(2): 120-122$.

10. Friedman S.L., Sheppard D., Duffield J.S., Violette S. (2013) Therapy for fibrotic diseases: nearing the starting line. Sci. Transl. Med., 5: 167sr1.

11. Lee Y.A., Friedman S.L. (2014) Reversal, maintenance or progression: what happens to the liver after a virologic cure of hepatitis (? Antiviral. Res., 107: 23.

12. Klein S., Mittendorfer B., Eagon J.C. et al. (2006) Gastric bypass surgery improves metabolic and hepatic abnormalities associated with nonalcoholic fatty liver disease. Gastroenterology, 130: 1564.

13. KhalafN., White D., Kanwal F. et al. (2015) Coffee and Caffeine Are Associated With Decreased Risk of Advanced Hepatic Fibrosis Among Patients With Hepatitis C. Clin. Gastroenterol. Hepatol., 13: 1521.

14. Melhem A., Muhanna N., Bishara A. et al. (2006) Anti-fibrotic activity of NK cells in experimental liver injury through killing of activated HSC. J. Hepatol., 45: 60. 
15. Jeong W.I., Park 0., Gao B. (2008) Abrogation of the antifibrotic effects of natural killer cells/interferon-gamma contributes to alcohol acceleration of liver fibrosis. Gastroenterology, $134: 248$.

16. Sanyal A.J., Chalasani N., Kowdley K.V. et al. (2010) Pioglitazone, vitamin E, or placebo for nonalcoholic steatohepatitis. N. Engl. J. Med., 362: 1675.

17. Trappoliere M., Caligiuri A., Schmid M. et al. (2009) Silybin, a component of sylimarin, exerts antiinflammatory and anti-fibrogenic effects on human hepatic stellate cells. J. Hepatol., 50: 1102.

\section{Promising opportunities to prevent the appearance and progression of liver fibrosis}

\section{O.V. Shvets}

Ukrainian Gastroenterological Association

\section{Відомості про автора:}

Швець Олег Віталійович — лікар-терапевт вищої категорії, лікар-гастроентеролог вищої категорії, лікар-дієтолог вищої категорії, кандидат медичних наук, доцент, Голова Комітету 3 міжнародної роботи, директор ДП «Державний науково-дослідний центр з проблем гігієни харчування М0З України», Київ, Україна.

\section{Адреса для кореспонденції:}

Швець Олег Віталійович

01042, Київ, вул. Чигоріна, 18

E-mail: hyppocrat@gmail.com
Abstract. The pathophysiological mechanisms of liver fibrosis are considered in the article. It is noted that liver fibrosis is a sign of progression of chronic diffuse liver disease, its slowing down and regression is the goal of hepatoprotective therapeutic interventions. Effective etiotropic therapy, individual diet therapy and the use of optimal hepatoprotectors can prevent the appearance and progression of liver fibrosis. The basic principles of hepatoprotective therapy and characteristics of hepatoprotective drugs are given. An innovative complex of amino acid derivatives with hepatoprotective properties Livodinol ${ }^{\circledR}$ is presented, which allows to achieve a therapeutic goal in various chronic diffuse liver diseases.

Key words: chronic diffuse liver disease, liver fibrosis, liver cirrhosis, hepatoprotectors, Livodinol ${ }^{\circledast}$.

\section{Information about the author:}

Shvets Oleg V. - MD, therapist of the highest category, gastroenterologist of the highest category, dietitian of the highest category, Candidate of Medical Sciences, Associate Professor, Head of the Committee on International Work, Director of the State Enterprise «State Research Center for Nutrition Hygiene of the Ministry of Health of Ukraine», Kyiv, Ukraine.

\section{Address for correspondence:}

Oleg Shvets

01042, Kyiv, Chyhorina str., 18

E-mail: hyppocrat@gmail.com 